\title{
HUBUNGAN ANTARA STATUS SOSIAL EKONOMI KELUARGA DENGAN KEMATIAN PERINATAL DI WILAYAH KERJA PUSKESMAS BAAMANG UNIT II SAMPIT KALIMANTAN TENGAH JANUARI-APRIL 2010
}

\author{
Septiana Dwi Susanti Aisyan, Sitti Nur Djannah, Yuniar Wardani \\ Fakultas Kesehatan Masyarakat, Universitas Ahmad Dahlan, Yogyakarta
}

\begin{abstract}
Background: Mortality is an indicator of perinatal health status of mothers and children in the general obstetric service. Puskesmas Baamang Unit II Sampit is one of the health service in the town of Sampit who are ready to provide health services to the community. Socioeconomic factors such as education, knowledge about health, nutrition and environmental health, beliefs, values, and poverty is an individual and family factors that affect mortality in the community. Low socioeconomic women who are unable to meet the daily needs because of economic constraints so that women's nutritional needs are not fulfilled, this will have an impact on pregnancy. The purpose of this study to determine the relationship between socioeconomic status families with perinatal mortality in the working area Puskesmas Baamang Unit II Sampit.

Methods: This was an observational research with cross sectional design. Total sample of 81 people. Samples were taken with a total sampling technique, using primary and secondary.

Results: This study showed that there was a relationship between the social economy of perinatal death with a family with a $C C$ value $=0.636 ; X^{2}$ count $>X^{2}$ table $(12.271>3.841)$ and Approx. $.000 \mathrm{Sig}$ is smaller than a (0.05).

Conclusion: There was a relationship between socioeconomic status families with perinatal mortality in the Puskesmas Baamang Unit II Sampit in Central Kalimantan.
\end{abstract}

Key words: perinatal, Imortality, socioeconomic status, family.

\section{PENDAHULUAN}

Derajat kesehatan dan sosial suatu bangsa dapat dinilai dari beberapa indikator antara lain angka kematian bayi, angka kematian ibu dan umur harapan hidup. Kematian bayi itu sendiri tidak dapat dipisahkan dari baik buruknya kesehatan ibu. Rawannya derajat kesehatan ibu juga sangat mempengaruhi kondisi kesehatan janin yang dikandungnya. Kejadian lahir mati dan kematian bayi pada minggu pertama kehidupannya dipengaruhi oleh kondisi selama kehamilan, komplikasi pada ibu dan bayi baru lahir serta pertolongan persalinan, disamping itu kondisi yang berkaitan dengan perawatan bayi baru lahir pada masa perinatal. ${ }^{1}$

Indonesia sebagai salah satu negara berkembang telah menunjukkan hal yang menggembirakan karena angka kematian bayi telah menurun. Berdasarkan perhitungan dari Badan Pusat Statistik (BPS), pada tahun 2007 diperoleh Angka Kematian Bayi (AKB) sebesar 26,9 per 1000 kelahiran hidup, angka ini sudah jauh menurun dibandingkan tahun 2002-2003 sebesar 35 per 1000 kelahiran hidup. Adapun target AKB pada Milenium Development Goals (MDGS) 2015 sebesar 17 per 1000 kelahiran hidup. Meski demikian penurunan angka ini masih tinggi bila dibandingkan dengan angka kematian bayi di negara ASEAN lainnya.

Kematian perinatal merupakan indikator derajat kesehatan ibu dan anak dalam pelayanan obstetrik secara umum. Kematian perinatal merupakan masalah yang membutuhkan perhatian secara serius dibeberapa negara termasuk Indonesia. Berbagai program dan pelayanan telah dilakukan untuk menurunkan kejadian perinatal misalnya 
promosi kesehatan, pembagian pamflet belum menunjukkan hasil yang optimal. ${ }^{1}$

Faktor usia ibu kurang dari 20 tahun atau diatas 35 tahun salah satu penyebab kematian perinatal, dimana ibu-ibu yang terlalu muda seringkali secara emosional dan fisik belum matang, selain pendidikan pada umumnya rendah, ibu yang masih muda masih tergantung kepada orang lain. Hal tersebut juga dipengaruhi oleh faktor sosial ekonomi yang rendah. Jarak kehamilan kurang dari 2 tahun dapat menimbulkan pertumbuhan janin kurang baik, persalinan lama dan perdarahan pada saat persalinan karena keadaan rahim belum pulih dengan baik. Paritas ibu dengan jumlah anak lebih dari 4 dapat menimbulkan gangguan pertumbuhan janin sehingga melahirkan bayi dengan berat lahir rendah dan perdarahan saat persalinan karena keadaan rahim biasanya sudah lemah. ${ }^{2}$

Di Indonesia terutama di daerah pedesaan masih banyak wanita yang pendidikannya rendah dan dan sosial ekonominya juga rendah sehingga masih banyak terdapat perkawinan di usia muda. Kebiasaan ini berasal dari adat yang berlaku sejak dahulu yang masih ada sampai sekarang. Ukuran perkawinan di masyarakat seperti itu adalah kematangan fisik, (haid, bentuk tubuh yang sudah menunjukkan tanda-tanda seksual sekunder), atau bahkan hal-hal yang sama sekali tidak ada kaitnya dengan calon pengantin. ${ }^{3}$ Fakta masih tingginya pernikahan diusia remaja sejalan dengan adanya kehamilan diusia remaja. Kehamilan usia dini memuat risiko yang cukup berat. Emosional ibu belum stabil dan ibu mudah tegang. Kecacatan kelahiran dapat muncul akibat ketegangan saat dalam kandungan, adanya rasa penolakan secara emosional ketika ibu mengandung bayinya. Usia merupakan faktor penting dalam menentukan waktu yang ideal untuk hamil, usia remaja lebih berisiko mengalami komplikasi pada kehamilannya, serta angka kematian bayi lebih tinggi terjadi pada remaja yang hamil. Remaja yang sudah menjadi ibu biasanya belum siap secara finansial dan emosi untuk memiliki anak. ${ }^{4}$

Faktor sosial ekonomi seperti pendidikan, pengetahuan tentang kesehatan, gizi dan kesehatan lingkungan, kepercayaan, nilai-nilai, dan kemiskinan merupakan faktor individu dan keluarga, mempengaruhi mortalitas dalam masyarakat. Faktor pendidikan ibu merupakan faktor pengaruh yang kuat terhadap kematian bayi. Pendidikan pada hakekatnya merupakan usaha sadar untuk mengembangkan kepribadian dan kemampuan di dalam dan luar sekolah seumur hidup sehingga makin matang dalam menghadapi dan memecahkan berbagai masalah termasuk masalah kesehatan dalam rangka menekan risiko kematian. Pendidikan ibu sangat erat kaitannya dengan reaksi serta pembuatan keputusan rumah tangga terhadap penyakit. Ini terlihat bahwa kematian balita yang rendah dijumpai pada golongan wanita yang mempunyai pendidikan yang tinggi. Tinggi rendahnya tingkat pendidikan ibu erat kaitannya dengan tingkat pengertian terhadap perawatan kesehatan, higiene, perlunya pemeriksaan kehamilan.

Perbedaan tingkat kematian perinatal antara daerah perdesaan dan perkotaan dapat dilihat menurut karakteritik sosio ekonomi wanita yang mencerminkan perilaku seorang ibu meliputi cara hidup sehat dan konsumsi gizi. Wanita hamil yang kekurangan gizi akan cenderung untuk mengalami anemia yang berdampak pada kelahiran bayi dengan berat badan lahir rendah yang sangat rentan terhadap penyakit yang dapat berdampak pada kematian. Wanita yang sosial ekonominya rendah tidak dapat memenuhi kebutuhannya sehari-hari karena keterbatasan ekonomi sehingga kebutuhan gizi wanita tersebut tidak tercukupi, hal ini akan berdampak pada kehamilan.

Kematian perinatal masih cukup tinggi dan masih banyak dijumpai di wilayah kerja Puskesmas Baamang Unit II Sampit Kalimantan Tengah. Berdasarkan data yang diperoleh dari laporan Puskesmas Baamang Unit II Sampit Kalimantan Tengah jumlah kasus kematian bayi pada tahun 2010 dari Januari sampai dengan April terdapat 8 kematian perinatal dari 81 kelahiran hidup. Berdasarkan informasi dari petugas kesehatan Puskesmas Baamang Unit II Sampit Kalimantan Tengah sebagian besar 
pasien yang melakukan persalinan di Puskesmas Baamang Unit II Sampit Kalimantan Tengah berasal dari ekonomi menengah ke bawah. Banyak keluarga yang kurang mampu atau miskin yang bersalin di puskesmas tersebut. Berdasarkan uraian di atas, peneliti merasa perlu melakukan penelitian dengan tujuan mengetahui hubungan antara sosial ekonomi keluarga dengan kejadian lahir mati pada bayi di wilayah kerja Puskesmas Baamang Unit II Sampit Kalimantan Tengah Januari-April 2010.

\section{METODE PENELITIAN}

Penelitian ini merupakan penelitian observasional analitik dengan rancangan studi cross sectional. Cross sectional adalah metode pengumpulan data dimana informasi yang dikumpulkan hanya pada satu saat tertentu. ${ }^{5}$

Instrumen penelitian ini diperoleh dari data sekunder dan data primer. Data sekunder diperoleh dari rekam medis Puskesmas Baamang Unit II Sampit dan data primer diperoleh dari lembar tentang status sosial ekonomi keluarga.

\section{HASIL PENELITIAN DAN PEMBAHASAN}

\section{a. Hasil Penelitian}

1) Gambaran Umum Lokasi Penelitian

Puskesmas Baamang Unit II terletak di Jalan Hasan Mansyur No. 51 Kecamatan Baamang Kota Sampit Kalimantan Tengah. Kecamatan Baamang mempunyai luas wilayah sebesar $271 \mathrm{Km}^{2}$ yang terdiri dari 1 kelurahan dan 3 desa, tersebar di jalur Sungai Mentaya. Batas-batas wilayah Puskesmas Baamang Unit II adalah sebagai berikut:
a) Sebelah utara
: Kecamatan Kotabesi
b) Sebelah timur
: Desa Baamang Tengah
c) Sebelah selatan
: Hutan Negara
d) Sebelah barat
: Hutan negara

Penanganan kematian bayi perinatal di Puskesmas Baamang Unit II Sampit yaitu dengan dilakukannya promosi kesehatan melalui penyuluhan, penyebaran pamflet, brosur yang berisi tentang makanan-makanan bergizi pada ibu hamil dan mempromosikan pentingnya ibu hamil untuk memeriksa dan memantau perkembangan dan pertumbuhan janin pada masa kehamilan.

2) Karakteristik Responden

Jumlah subyek penelitian ini adalah 81 responden dengan pengambilan sampel secara total sampling di wilayah kerja Puskesmas Baamang Unit II Sampit Kalimantan Tengah. Karakteristik responden pada penelitian ini meliputi identitas bayi dan identitas ibu. Identitas ibu meliputi karakteritisk usia, pendidikan, pekerjaan, penghasilan keluarga perbulan dan pemeriksaan kehamilan (ANC). Adapun karakteristik responden dapat dilihat pada tabel di bawah ini. 
Tabel 1. Karakteristik Responden Berdasarkan Usia Ibu di Wilayah Kerja Puskesmas Baamang Unit II Sampit

\begin{tabular}{lcc}
\hline No $\quad$ Karakteristik & Jumlah & Persentase \\
\hline Umur ibu & & \\
a. $<20$ tahun & 12 & 15 \\
b. $20-35$ tahun & 65 & 80 \\
c. $>35$ tahun & 4 & 5 \\
\hline \multicolumn{1}{c}{ Total } & 81 & $100 \%$ \\
\hline
\end{tabular}

Berdasarkan tabel 1 di atas dapat dilihat bahwa sebagian besar responden mempunyai usia dengan rentang umur 20 sampai 35 tahun yaitu sebesar $65(80 \%)$. Hal ini dikarenakan pada masa umur tersebut merupakan masa produktif perempuan, sehingga sebagian besar responden mempunyai umur dalam rentang tersebut untuk hamil dan melahirkan, sedangkan responden yang mempunyai umur di atas 35 tahun sebanyak 4 responden (5\%).

Tabel 2. Karakteristik Responden Berdasarkan Pendidikan Ibu di Wilayah Kerja Puskesmas Baamang Unit II Sampit

\begin{tabular}{|c|c|c|c|}
\hline No & Karakteristik & Jumlah & Persentase \\
\hline \multicolumn{4}{|c|}{ Pendidikan } \\
\hline & a. SD & 19 & 23 \\
\hline & b. SMP & 35 & 43 \\
\hline & c. SMA & 24 & 30 \\
\hline & d. Perguruan Tinggi & 3 & 4 \\
\hline & Total & 81 & $100 \%$ \\
\hline
\end{tabular}

Dari tabel 2 terlihat bahwa pendidikan responden lebih banyak dalam tingkat pendidikan SMP sebesar 35 responden (43\%), sedangkan tingkat pendidikan perguruan tinggi sebesar 3 responden (4\%).

Tabel 3. Karakteristik Responden Berdasarkan Pekerjaan Ibu di Wilayah Kerja Puskesmas Unit II Sampit

\begin{tabular}{|c|c|c|c|}
\hline No & Karakteristik & Jumlah & Persentase \\
\hline & $\begin{array}{l}\text { Pekerjaan } \\
\text { a. Pedagang } \\
\text { b. Ibu rumah tangga } \\
\text { c. Karyawan swasta } \\
\text { d. Guru } \\
\text { e. Pegawai Negeri Sipil } \\
\text { f. Buruh }\end{array}$ & $\begin{array}{c}33 \\
27 \\
15 \\
3 \\
2 \\
1\end{array}$ & $\begin{array}{c}41 \\
33 \\
19 \\
4 \\
2 \\
1\end{array}$ \\
\hline & Total & 81 & $100 \%$ \\
\hline
\end{tabular}

Pada tabel 3 tersebut juga menunjukkan bahwa sebagian besar responden pekerjaannya sebagai pedagang sebesar 33 orang $(41 \%)$, sedangkan responden yang mempunyai pekerjaan sebagai buruh sebesar 1 responden $(1 \%)$. 
Tabel 4. Karakteristik Responden Berdasarkan Pemeriksaan Kehamilan dii Wilayah Kerja Puskesmas Unit II Sampit

\begin{tabular}{|c|c|c|c|}
\hline No & Karakteristik & Jumlah & Persentase \\
\hline \multicolumn{4}{|c|}{ Pemeriksaan kehamilan (ANC) } \\
\hline & & 1 & 1 \\
\hline \multirow{2}{*}{\multicolumn{2}{|c|}{ b. 2 kali }} & 12 & 15 \\
\hline & & 36 & 44 \\
\hline \multicolumn{2}{|c|}{ c. 3 kali } & 32 & 40 \\
\hline \multicolumn{4}{|c|}{ d. $\geq 4$ kali } \\
\hline & Total & 81 & $100 \%$ \\
\hline
\end{tabular}

Berdasarkan tabel 4 terlihat bahwa pemeriksaan kehamilan responden lebih banyak 3 kali selama kehamilan yaitu sebesar 36 responden (44\%), sedangkan 1 kali sebesar 1 responden (1\%).

Tabel 5. Karakteristik Menurut Kejadian Perinatal di Wilayah Kerja Puskesmas Baamang Unit II Sampit

\begin{tabular}{llcc}
\hline No & Karakteristik & Jumlah & Persentase \\
\hline 1 & Kelahiran Bayi & & \\
& a. Perinatal mati & 8 & 9 \\
& b. Perinatal hidup & 73 & 91 \\
\hline \multicolumn{1}{c}{ Total } & 81 & $100 \%$ \\
\hline
\end{tabular}

Berdasarkan Tabel 5 di atas dapat dilihat bahwa sebagian besar responden Puskesmas Baamang Unit II Sampit mempunyai bayi perinatal hidup yaitu sebesar $73(91 \%)$, akan tetapi juga terlihat jumlah bayi dengan perinatal mati sebesar 8 responden (9\%). Karakterstik responden berdasarkan identitas ibu dapat dilihat pada tabel di bawah ini.

Tabel 6. Karakteristik Responden Berdasarkan Penghasilan Keluarga Perbulan di Wilayah Kerja Puskesmas Baamang Unit II Sampit

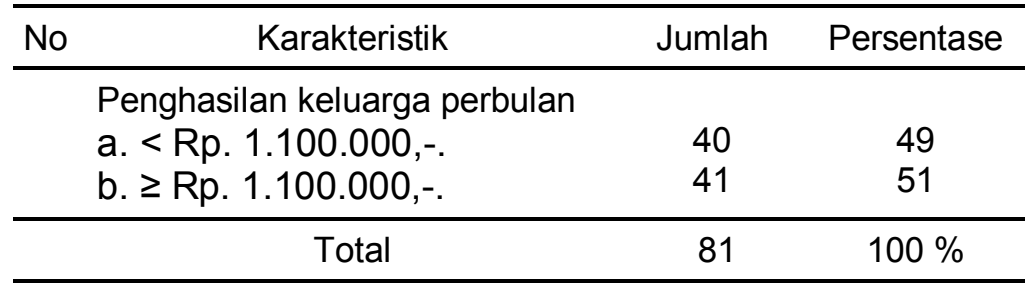

Pada tabel 6 tersebut menunjukkan bahwa sebagian besar penghasilan keluarga perbulan responden $\geq R p$. 1.100.000,- sebanyak 41 responden (\%), dan responden yang penghasilan keluarga perbulan Sebesar $<$ Rp. 1.100.000,sebanyak 40 responden (\%).

\section{3) Analisis Bivariat}

Analisis bivariat dilakukan untuk mengetahui hubungan antara sosial ekonomi keluarga dengan kematian bayi perinatal. Analisis yang digunakan 
dalam penilitian ini adalah chi-square. Berikut adalah hasil perhitungan yang telah dilakukan.

\begin{tabular}{|c|c|c|c|c|c|c|c|c|c|c|}
\hline \multirow{3}{*}{\multicolumn{2}{|c|}{$\begin{array}{l}\text { Status Eko- } \\
\text { nomi Keluarga }\end{array}$}} & \multicolumn{6}{|c|}{ Kematian Bayi Perinatal } & \multirow{3}{*}{$\begin{array}{l}\text { Approx } \\
\text {.sig }\end{array}$} & \multirow{3}{*}{$\begin{array}{c}\text { Value } X^{2} \\
\text { Hitung }\end{array}$} & \multirow{3}{*}{$\begin{array}{l}\text { Value } \\
\text { Coef. } \\
\text { Conti. }\end{array}$} \\
\hline & & \multicolumn{2}{|c|}{$\begin{array}{c}\text { Perinatal } \\
\text { Mati }\end{array}$} & \multicolumn{2}{|c|}{$\begin{array}{l}\text { Perinatal } \\
\text { Hidup }\end{array}$} & \multicolumn{2}{|c|}{ Total } & & & \\
\hline & & $\Sigma$ & $\%$ & $\Sigma$ & $\%$ & $\Sigma$ & $\%$ & & & \\
\hline 1 & Rendah & 8 & 0 & 26 & 32 & 34 & 42 & & & \\
\hline 2 & Tinggi & 0 & 0 & 47 & 58 & 47 & 58 & 0,000 & 12,271 & 0,363 \\
\hline 3 & Total & 8 & 10 & 73 & 90 & 81 & 100 & & & \\
\hline
\end{tabular}

Dari tabel 7 terlihat bahwa sosial ekonomi keluarga yang rendah didapatkan bayi perinatal mati sebesar 10 persen dan sosial ekonomi tinggi didapatkan bayi perinatal hidup sebesar 58 persen. Hasil uji statistik chi square dengan bantuan komputer didapatkan nilai $X^{2}$ hitung $>X^{2}$ tabel $(12,271>3,841)$ dan nilai Approx. Sig adalah 0,000 lebih kecil dari a $(0,05)$, ini menyatakan bahwa ada hubungan yang bermakna antara sosial ekonomi keluarga dengan kematian bayi perinatal dengan besar hubungan sebesar 36,3 persen dilihat dari nilai CC (Coefisien Contingency).

\section{b. Pembahasan}

\section{1) Karakteristik Ibu}

Berdasarkan dari hasil penelitian, ibu yang berusia kurang dari 20 tahun berisiko terhadap kematian bayi perinatal yaitu ibu yang berusia 14 tahun, 16 tahun, 17 tahun dan 18 tahun. Usia kurang dari 20 tahun disebabkan karena organ resproduksi yang belum matang atau mature. Usia kurang dari 20 tahun adalah ibu-ibu yang terlalu muda seringkali secara emosional dan fisik belum matang, selain pendidikan pada umumnya rendah, ibu yang masih muda masih tergantung pada orang lain.

Kehamilan di bawah umur sangat berisiko tetapi kehamilan di atas usia 35 tahun juga tidak dianjurkan dan sangat berbahaya. Mengingat mulai usia ini sering muncul penyakit seperti hipertensi, tumor jinak peranakan, atau penyakit degeneratif pada persendian tulang belakang dan panggul. Kesulitan lain kehamilan di atas usia 35 tahun ini yakni bila ibu ternyata mengidap penyakit seperti diatas yang ditakutkan bayi lahir dengan membawa kelainan. ${ }^{6}$ Berdasarkan proses persalinan sendiri, kehamilan di usia lebih dari 35 tahun ini akan menghadapi kesulitan akibat lemahnya kontraksi rahim serta sering timbul kelainan pada tulang panggul tengah. Banyaknya komplikasi yang dapat muncul pada kehamilan di atas 35 tahun dapat menyebabkan kematian bayi perinatal. Di wilayah kerja Puskesmas Baamang Unit II Sampit masih ada ibu yg melahirkan pada usia lebih dari 35 tahun dan hasilnya kematian perinatal yaitu ibu usia 36 tahun, 38 tahun dan 39 tahun. Usia merupakan faktor yang penting untuk mengurangi dan mencengah terjadinya kematian perinatal sehingga dapat menurunkan angka kematian dan kesakitan pada bayi. Sikap seseorang sangat dipengaruhi oleh pengalaman dan kematangan usia. ${ }^{\text {? }}$

Berdasarkan data karakterstik responden yang terbanyak yaitu usia 20-35 tahun yang menunjukkan bahwa usia tersebut merupakan usia dewasa sehingga kematangan dalam berfikir dan mengambil keputusan untuk merubah sikap berdasarkan pengetahuan yang benar tentang masa kehamilan dalam 
mencengah terjadinya kematian perinatal, tetapi pada usia 20-35 tahun juga terdapat responden yang bayinya perinatal mati yaitu pada ibu yang berusia 22 tahun.

Kematian perinatal adalah salah satu masalah kesehatan yang utama di Indonesia karena masih tingginya angka kematian bayi. Host, lingkungan dan sosiokultural merupakan beberapa variabel yang dapat mempengaruhi insiden dan keparahan kejadian kematian perinatal. Pengetahuan seseorang biasanya dipengaruhi oleh faktor tingkat pendidikan, sumber informasi, keterlibatan ibu dalam masyarakat, sosial ekonomi, budaya, dan pengalaman. Pengetahuan ini dapat membentuk keyakinan tertentu sehingga seseorang berperilaku sesuai keyakinan tersebut.

Pendidikan ibu yang rendah akan berpengaruh dengan kematian perinatal. Hal ini disebabkan karena faktor tingkat pendidikan yang rendah akan menyebabkan rendahnya pengetahuan sehingga akan berpengaruh terhadap pengetahuan ibu saat hamil. Pada penelitian ini, didapatkan tingkat pendidikan ibu di wilayah kerja Puskesmas Baamang Unit II Sampit ini rata-rata tingkat pendidikannya SMP. Seorang ibu bertanggung jawab merawat anak sangat dipengaruhi oleh tingkat pendidikan ibu. Pada penelitian ini, jumlah responden yang mempunyai tingkat pendidikan SMP yaitu 35 responden sehingga kemungkinan ada hubungan bermakna antara tingkat pendidikan responden dengan kematian bayi perinatal. Faktor tingkat pendidikan mempunyai peran dalam mengakses pengetahuan sehingga menimbulkan suatu perilaku. Pendidikan ibu yang rendah menyebabkan ibu tersebut tidak mengetahui usia ideal untuk menikah, hamil dan melahirkan. Di wilayah kerja Puskesmas Baamang Unit II Sampit responden yang melahirkan perinatal mati yaitu yang pendidikannya SD 3 responden, pendidikannya SMP 4 responden dan yang pendidikannya SMA 1 responden.

Pendidikan yang rendah menyebabkan beberapa ibu hamil tidak mengetahui pentingnya pemeriksaan saat kehamilan (antenatal care), padahal dari pihak Puskesmas Baamang Unit II Sampit sudah membebaskan biayanya. Pada tabel 4 terlihat bahwa ibu yang rutin memeriksakan kehamilannya lebih atau sama dengan 4 kali hanya 32 responden dari 81 responden.

Hasil penelitian menunjukkan bahwa sebagian besar ibu yang memiliki pekerjaan mempunyai risiko terhadap kematian perinatal. Ibu yang mempunyai pekerjaan dalam penelitian ini termasuk ibu yang mampu menghasilkan uang baik di rumah maupun di luar rumah. Hasil penelitian menunjukkan bahwa ibu yang mempunyai pekerjaan dengan kelahiran bayi perinatal mati sebanyak 5 responden yang bekerja sebagai pedagang dan 1 responden bekerja sebagai karyawan swasta dan 2 responden sebagai ibu rumah tangga.

Diperkirakan bahwa seorang wanita dengan kondisi kesehatan yang baik dan dengan aktivitas kerja yang sedang, selama kehamilannya memerlukan tambahan sekitar 300 kalori sehari. Ibu yang bekerja cenderung kurang istirahat, tidak seimbang dalam mengonsumsi makanan. Berat ringannya pekerjaan ibu akan mempengaruhi kondisi tubuh dan akhirnya berpengaruh terhadap status kesehatan ibu. ${ }^{8}$

Keterlibatan perempuan dalam pekerjaan domestik dan pekerjaan berorientasi peningkatan ekonomi keluarga, ternyata tidak dibarengi asupan gizi memadai. Padahal perempuan juga mendapat tambahan tugas reproduksi yakni mengandung anak-anaknya. Beberapa studi di Asia dan Afrika menunjukkan, asupan kalori kaum perempuan hanya sekitar 50-70 persen. Bila perempuan kurang gizi pada saat mengandung, maka akan berpotensi terjadinya kematian perinatal. ${ }^{9}$

Pekerjaan yang mengharuskan seorang perempuan untuk membantu suami 
dalam meningkatkan taraf kehidupan dan kesejahteraan menjadi fenomena dari perempuan. Pekerjaan yang berat secara langsung menyebabkan terjadinya asupan gizi yang kurang atau tidak efektif dan efisisen sehingga menyebabkan kematian perinatal. Status pekerjaan mempunyai risiko dalam meningkatkan terjadinya kematian bayi perinatal, dengan pekerjaan yang menguras tenaga sehingga mengganggu asupan zat gizi dan akan meningkatkan terjadinya risiko kematian perinatal.

\section{2) Status Sosial Ekonomi Keluarga}

Penghasilan keluarga merupakan salah satu tema penting dalam mengelola keuangan keluarga, karena besarnya uang masuk akan mempengaruhi besarnya uang yang akan dikeluarkan. Penghasilan adalah gaji tetap yang diterima setiap bulan. Penghasilan akan erat kaitannya dengan kemampuan orang untuk memenuhi kebutuhan gizi, perumahan yang sehat, pakaian dan kebutuhan lain yang berkaitan dengan pemeliharaan kesehatan. ${ }^{8}$

Status ekonomi masyarakat di wilayah kerja Puskesmas Baamang Unit II Sampit dapat dikatakan rendah karena masih dibawah upah minimum regional (UMR) kota Sampit yaitu kurang dari Rp 1.100.000,-. Terbukti pada tabel 6 ratarata penghasilan keluarga tiap bulannya kurang dari Rp 1.100.000,- sebanyak 40 responden dan 41 responden yang penghasilan keluarga tiap bulannya lebih dari pada itu. Status ekonomi yang rendah menjadi penyebab tidak langsung terjadinya kematian perinatal.

Keluarga yang berpenghasilan di bawah UMR sangat kesulitan dalam mencukupi kebutuhan gizinya sehari-hari. Ibu hamil tidak dapat memenuhi kebutuhan gizinya padahal gizi ibu hamil sangat penting. Setiap hari makan seadanya saja, yang penting makan tanpa mengetahui makanan yang dikonsumsi tersebut mengandung nilai gizi atau tidak. Keluarga yang berpenghasilan rendah juga rata-rata berpendidikan rendah sehingga tidak mengerti akan kesehatan pada saat kehamilan, tidak tahu kebutuhan gizi ibu hamil dan tidak memeriksa dan merawat kehamilan dengan baik.

\section{3) Kematian Perinatal}

Kematian perinatal di wilayah kerja Puskesmas Baamng Unit II Sampit tergolong tinggi. Berdasarkan data dari bulan Januari sampai dengan April 2010 terdapat 8 kematian perinatal, 1 kematian neonatal dan 1 partus macet dari 70 jumlah kelahiran hidup. Kematian perinatal di wilayah kerja Puskesmas Baamang Unit II Sampit berhubungan secara tidak langsung dengan status sosial ekonomi keluarga karena wanita hamil yang sosial ekonominya rendah tidak dapat memenuhi kebutuhan gizinya sehari-hari. Sosial ekonomi juga berkaitan dengan faktor pendidikan, wanita yang berpendidikan rendah tidak mengerti pentingnya pemeriksaan kehamilan jadi wanita tersebut tidak pernah atau jarang memeriksakan kehamilannya dan dari pihak Puskesmas Baamang Unit II Sampit pun jarang melakukan penyuluhan kepada masyarakat setempat sehingga masyarakat tidak mengerti.

\section{4) Hubungan Antara Sosial Ekonomi Keluarga dengan Kematian Perinatal}

Berdasarkan penelitian yang telah dilakukan, hasil penelitian yang sama yang pernah dilakukan menunjukkan bahwa determinan sosial ekonomi secara signifikan berkorelasi dengan kematian bayi perinatal. Faktor sosio-ekonomi merupakan faktor penentu mortalitas bayi dan anak. Determinan sosial-ekonomi kesehatan adalah kondisi-kondisi sosial dan ekonomi yang melatari kehidupan seorang, yang mempengaruhi kesehatan. Faktor penyebab tingginya angka kematian bayi adalah kemiskinan. Banyak kasus bayi meninggal karena ibunya 
mengalami kurang gizi. Status gizi individu atau komunitas-dipengaruhi oleh faktor ekonomi dan ekologi sosial. ${ }^{10}$

Di negara sedang berkembang seperti Indonesia, faktor selain teknis medis seperti faktor geogafis, karakteristik ibu dan ayah, serta faktor keadaan sosial ekonomi sangat besar peranannya, mengingat kawasan Indonesia yang luas dan belum merata kondisinya atau adanya perbedaan yang besar dalam bidang sosial dan ekonomi. Perbedaan tingkat kematian perinatal antara daerah perdesaan dan perkotaan dapat dilihat menurut karakteritik sosio-ekonomi wanita yang mencerminkan perilaku seorang ibu meliputi cara hidup sehat dan konsumsi gizi. Tinggi atau rendahnya angka kematian sangat erat hubungannya dengan kesejahteraan masyarakat dalam arti makin tinggi pendidikan dan pendapatan akan cenderung untuk mencegah terjadinya kematian perinatal.

Sosial ekonomi yang terkait dengan angka kematian perinatal, pengunjung Baamang Unit II Sampit cenderung berasal dari kelompok masyarakat dengan tingkat sosial-ekonomi yang rendah. Kemiskinan masih menjadi penyebab utama tingginya angka kematian perinatal disana. Di negara maju dan kaya, mayoritas perempuan melahirkan dengan ditangani tenaga ahli kesehatan. Kematian perinatal juga umumnya terjadi di daerah terpencil yang minim tenaga dokter dan perawat. Faktor kemiskinan dan ketidaktahuan disinyalir menjadi penyebab tingginya angka kematian perinatal. Padahal, angka tersebut dapat dicegah, jika masyarakat mau berperan serta dan mengupayakan keselamatannya sendiri. Apalagi dengan perkembangan teknologi kedokteran yang semakin maju, bukan mustahil angka kematian perinatal dapat ditekan.

Berdasarkan tabel 7 diperoleh hasil penelitian sebanyak 8 responden yang sosial ekonomi keluarga rendah dan perinatal mati, 26 responden yang sosial ekonomi rendah dan perinatal hidup. Tidak ada responden yang sosial ekonomi tinggi yang perinatal mati dan 47 responden yang sosial ekonomi tinggi dan perinatal hidup. Hal ini menunjukkan bahwa sosial ekonomi yang rendah merupakan faktor penyebab kematian bayi perinatal di wilayah kerja Puskesmas Baamang Unit II. Hubungan sosial ekonomi keluarga dengan kematian bayi perinatal di Puskesmas Baamang Unit II Sampit dengan melihat nilai $X^{2}$ hitung > $X^{2}$ tabel $(12,271>3,841)$. Hal ini berarti sosial ekonomi keluarga yang rendah dapat mempengaruhi kematian bayi perinatal dengan besar hubungan 36,3 persen dilihat dari nilai CC (Coefisien Contingency).

\section{SIMPULAN DAN SARAN}

\section{a. Simpulan}

Berdasarkan hasil analisis dan pembahasan yang telah diuraikan sebelumnya, dapat ditarik kesimpulan sebagai berikut :

1) Status sosial ekonomi keluarga di wilayah kerja Puskesmas Baamang Unit II adalah 40 responden berpenghasilan di bawah UMR dan 41 responden berpenghasilan di atas UMR.

2) Jumlah kematian perinatal di wilayah kerja Puskesmas Baamang Unit II Sampit adalah 8 kematian perinatal.

3) Ada hubungan antara status sosial ekonomi keluarga dengan kematian bayi perinatal di wilayah kerja Puskesmas Baamang Unit II Sampit Kalimantan Tengah. 


\section{b. Saran}

Berdasarkan hasil penelitian yang diperoleh, maka disarankan beberapa hal sebagai berikut:

1) Bagi Puskesmas Baamang Unit II Sampit

Meningkatkan penyuluhan, pembagian pamflet dan brosur makanan bergizi dan pemberian informasi tentang antenatal care kepada masyarakat khususnya ibu hamil sehingga materi yang diberikan dapat diserap, dipahami dan dilaksanakan.

1) Bagi peneliti lain

Bagi peneliti yang ingin meneliti tentang kematian perinatal sebaiknya mengambil beberapa faktor resiko dengan meneliti resiko yang paling dominan yang dapat meningkatkan kematian perinatal sehingga mampu mengurangi angka kematian dan kesakitan bayi.

\section{DAFTAR PUSTAKA}

1. Depkes RI, Pedoman Teknis Audit Maternal-Perinatal di Tingkat Kabupaten/Kota, Jakarta, 2002

2. Manuaba, I.B.G., IImu Kebidanan, Penyakit Kandungan dan Keluarga Berencana untuk Pendidikan Bidan, EGC, Jakarta, 1998

3. Ubaydillah, Resiko Tinggi Kehamilan Remaja (Usia Muda), http:/l creasoft.wordpress.com/, diambil tanggal 6 Mei 2010, Yogyakarta, 2000

4. Kountur, R., Metode Penelitian, Edisi Revisi, PPM, Jakarta, 2007

5. Sitorus, 1999

6. Adi, Mengatur Jarak Kehamilan, www-ibuhamil.blogspot.com, diambil pada tanggal 4 Mei 2010, Yogyakarta, 2009

7. Racmani, Menyambut Hadirnya Si Buah Hati, www.ayahbundaonline.com, diambil pada tanggal 6 Mei 2010, Yogyakarta, 2006

8. Khomsan, A., Perempuan dan Busung Lapar, www.kespro.info, diambil pada tanggal 24 Juli 2010, Yogyakarta, 2007

9. Mosley, W. Henry and Lincoln C. Chen, Child Survival Strategies for Research, Population Council: http://links.jstor.org/sici=0098-7921\%281984\%2910\%3C25\% 3AAAFFTS\%3E2.O.CO\%3B2-K, Cambridge University Press, USA, diambil pada tanggal 10 Juni 2010, Yogyakarta, 1984

10. Magriples, U., Kershaw, T.S., Rising, S.S., Massey, Z, \& icovics, J.R., prenatal health care beyond the obstettics services; utilization and predictor of unscheduled care, Am J obstet Gynecol 198 (1) :75.e 1-7, 2008 